\title{
REFERENCES
}

Barnes, P., and others. 1971. The friction and creep of polycrystalline ice, by P. Barnes, D. Tabor, and J. C. F. Walker. Proceedings of the Royal Society of London, Ser. A, Vol. 324, No. 1557, p. 127-55.

Budd, W. F. 1975. A first simple model for periodically self-surging glaciers. Journal of Glaciology, Vol. 14, No. 70 , p. $3^{-21}$.

Budd, W. F., and McInnes, B. J. 1974. Modeling periodically surging glaciers. Science, Vol. 186, No. 4167, p. $9^{25}-27$.

Budd, W. F., and others. I 979. Empirical studies of ice sliding, by W. F. Budd, P. L. Keage, and N. A. Blundy. Journal of Glaciology, Vol. 23, No. 89, p. i57-70.

\section{PRESSURE-MELTING WITHIN THE BASAL ICE OF AN ALPINE GLACIER INDICATED BY THE CHEMICAL COMPOSITION OF REGELATION ICE}

\author{
By R. Souchez, M. Lemmens, R. Lorrain, and J.-L. Tison \\ (Laboratoire de Géomorphologie, Faculté des Sciences, Université Libre de Bruxelles, \\ Avenue F. D. Roosevelt 50, B-105o Bruxelles, Belgium)
}

Abstract. In the heat-pump effect developed by Robin (1976), pressure-melting within the basal ice mass, as distinct from processes at the ice-bedrock interface, can be responsible for the formation of excess water in zones of high-pressure ice up-stream of obstacles. This water is squeezed out of the ice by the pressure and can refreeze at the interface to form regelation ice down-stream.

The peculiar chemical characteristics of regelation ice at the base of Glacier de Tsijiore Nouve in the Swiss Alps can only be explained by refreezing of this squeezed water. Melting at the interface up-stream of bed protuberances and refreezing of these melt waters downstream, as implied in Weertman's theory, can be excluded in this case.

This paper is published in full in Nature, Vol. 273, No. 5662, 1978, p. 454-56.

\section{REFERENCE}

Robin, G. de Q. 1976. Is the basal ice of a temperate glacier at the pressure melting point? Fournal of Glaciology, Vol. 16 , No. 74 , p. $183-96$.

\section{DISCUSSION}

B. Hallet: What do you think about the possibility of calcium and magnesium carbonates precipitating in basal ice around particles in the ice, thereby providing a sink for their divalent ions and causing relative enrichment of sodium and potassium in the water that is finally incorporated in the regelation ice?

R. A. Souchez: Precipitation of carbonates is precluded for the following reasons: (a) there is no lime coating on particles or on the gneissic bedrock; (b) if carbonate precipitation occurs at depth within the ice around particles, the eutectic calcium concentration in water must be reached. Now, if you take the minimum value for carbon dioxide partial pressure and a rather low distribution coefficient (o.or), regelation ice would have a minimum calcium content of I $3 \mu$ eq $\mathrm{l}^{-1}$. In fact, it has $6.4 \mu$ eq $\mathrm{l}^{-1}$ (mean value), which is smaller by a factor of two. 
HAllet: I agree that your measurements suggest that water is percolating through lowpermeability ice. However, the data do not indicate whether this is due to overall percolation of water from the surface or due to squeezing out of water from stressed basal ice, as Dr Robin suggests.

Souchez: There is no significant difference in major cations between surface glacier ice and basal glacier ice along the vertical above the regelation layer. If selective entrainment of alkalis by overall percolation is the dominant feature, one would expect a gradient to be present in glacier ice.

G. Holdsworth: Where were the melt-water samples taken for which the chemical analyses are given in the table? The minimum and maximum values of the chemical analyses given would presumably reflect the nature of sampling site(s) and these should be related to the sites of the ice sampling.

Souchez: At all the sampling sites (supraglacial, subglacial, or in the front of the glacier) all the values of the alkali-alkaline-earth ratio are lower than 0.15 , i.e. a factor of four less than that of regelation ice. This means that simple refreezing of these waters cannot explain the situation.

M. M. Herron: Have you measured $\mathrm{pH}$ or specific conductance on your samples to check on the applicability of the ion-exchange mechanism?

Souchez: No, we have not. In this case, $\mathrm{pH}$ measurements are difficult to interpret because of $\mathrm{pCO}_{2}$ fluctuations during melting. On the other hand, specific conductance is strongly affected by the dirt content.

\title{
IMPORTANGE OF PLASTIC DEFORMATION IN REGELATION OF IGE
}

\author{
By K. Tusima and $\mathrm{S}$. Tozuka \\ (Institute of Low Temperature Science, Hokkaido University, Sapporo, Japan o6o)
}

ABstraci. It is well known that regelation may occur by pressure-melting in front of a wire and refreezing at the rear. The velocity of the wire has been observed to have values ranging from $\mathrm{IO}^{-5}$ to $1 \mathrm{O}^{-1} \mathrm{~mm} / \mathrm{s}$. However, there have always been large discrepancies between experiments and any theory based on this mechanism, and, when moving at a comparable velocity, hard balls slid on an ice surface leave grooves made by plastic deformation. So, we conducted experiments to test whether regelation phenomena might be explained by plastic deformation of ice around the wire.

( I) Two single crystals of ice were vertically connected to a rigid base and a loop of copper was hung over the top of the ice with a weight attached. The velocity in the lower ice block which had its basal plane horizontal was $20 \%$ faster than that in the upper ice block where the basal plane was vertical, this result strongly suggests plastic deformation as the mechanism of regelation.

(2) An elliptical wire which had its long axis vertical moved five times more rapidly than one with its long axis horizontal, and when the long axis is inclined, the wire was deflected along the direction of the long axis. 